\title{
COMBINING ABILITY IN COCONUT (Cocos nucifera)
}

\author{
By \\ K.U.K.Nampoothiri, P.M. Kumaran, B.A. Jerard, M.J.Ratnambal E.V.V.B.Rao, \\ and V.A. Parthasarathy ${ }^{I}$
}

\section{INTRODUCTION}

Combining ability has been proved to be a method to identify and select the parents and hybrids for increased production through the exploitation of heterosis. The exploitation of heterosis would be useful if suitable hybrids are produced for low yielding environmental conditions of littoral sandy soil. Combining ability effects for early germination, seedling girth, seedling height and breadth of laminate leaf on coconut have been reported by Louis and Chopra (1991) and on husked nut weight by Fernando (1996). Estimation of GCA and SCA variance will help to find out the gene action involved in a particular character and thus one can decide the breeding method for the improvement of the character. The present investigation was carried out to find out the general and specific combining ability effects of parents and hybrids at Central Plantation Crops Research Institute, Kasaragod.

\section{MATERIALS AND METHODS}

Diallel crosses were made among the following nine coconut genotypes collected from different localities around the world.
1. West Coast Tall
- Kerala, India
2. Laccadive Ordinary
- Lakshadweep, India
3. San Ramon
- Philippines
4. Java
- Indonesia
5. Jamaica
- Jamaica
6. Fiji
- Fiji
7. Gangabondam
- India
8. Straight settlement Green
- Malaysia
9. New Guinea
- New Guinea

All the nine parents and 36 direct cross combinations $\left(\mathrm{F}_{1} \mathrm{~s}\right)$ were planted in the year 1972 in randomized block design with 2 replications in littoral sandy soils. The littoral sandy soil (Oxic quartzi $\mathrm{P}$ amments) has lower productivity owing to poor nutritional status, low CEC (0.4 to 5.4 $\mathrm{mc} / 100 \mathrm{~g}$ ) and organic carbon (0 to $0.46 \%$ ) (Khan et al. 1994). Basic characteristics of this soil with a pH of 5.9 is $98 \%$ saw, $0.2 \%$ silt, $0.7 \%$ clay, $0.025 \%$ Total N, 5 ppm available phosphorus and 20 $\mathrm{ppm}$ available potassium. The yield of nuts/palm/year was calculated and analysis taken up from the yield data for four years from 1992 to 1996. Data were subjected to the Griffing (1958) analysis method 2 for combining ability and Hayman (1954) for genetic components.

\footnotetext{
${ }^{1}$ Central Plantation Crops Research Institute, Kasaragod, 671-124 Kerala, India
} 


\section{RESULTS AND DISCUSSION}

Among the parents, the mean number of nuts/palm/year ranged from 14.5 in San Ramon to 66.1 in Java. The hybrid Laccadive Ordinary x Gangabondam recorded the highest number of nuts (102 nuts/palm/year) followed by Laccadive Ordinary x Straight Settlement Green (53.6 nuts/palm/year). The yield of hybrids over better parent indicates the hybrid vigour in LO x GB. The yields are low because the experiment was conducted in littoral sandy soils.

Analysis of variance for combining ability showed significant GCA and SCA variance suggesting the preponderance of both additive and non-additive gene action for number of nuts per palm. Presence of both additive and non-additive gene action shows the equal importance of crossing and selfing the selected individuals for improvement of the trait.

The GCA effect was positive and significant in three parents viz. Laccadive Ordinary (50.82), Gangabondam (14.29) and West Coast Tall (9.33). The higher values indicate the importance of these parents as good combiners in crossing programmes for the studied trait and offers opportunity for further selection. SCA effects was highest in the cross Laccadive Ordinary $\mathrm{x}$ Gangabondam followed by Fiji x New Guinea and West Coast Tall x San Ramon (Table 2).

Comparing the mean performance and the SCA effect, the cross Laccadive Ordinary $\mathrm{x}$ Gangabondam ranks first among the 36 hybrids evaluated. The parents of this cross are the best general combiners for the number of nuts/palm. Interestingly this is the only combination that showed heterosis over better parent.

The estimation of genetic components through diallel analysis (Table - 4) indicated that $\mathrm{D}$, a measure of addive effect is lower than $\mathrm{H}_{1}$ indicating over dominance. The components $\mathrm{H}_{1}$ and $\mathrm{H}_{2}$ measure the dominance effect of the genes. The component $h^{2}$ refers the dominance effect as the algebric sum over all loci in heterozygous phase in all crosses. F shows the mean of covariance of additive and dominance effects over the arrays. $\mathrm{F}$ is negative and non-significant which shows the unequal gene frequencies with frequent occurrence of recessive genes. The magnitude of $\mathrm{D}$ is lower than the $\mathrm{H}_{1}$ and $\mathrm{H}_{2}$ which indicated the preponderance of non-additive gene action in the genetic control. However, the expected environmental component of variation (E) was high and significant which suggests the inconclusive effects of the genetic components.

The proportion of $\left(\mathrm{H}_{1} / \mathrm{D}\right)^{1 / 2}$ is more than one indicating the mean degree of dominance as complete. The ratio of $\mathrm{H}_{2} / 4 \mathrm{H}_{1}(0.22)$ shows the unequal distribution of genes with positive and negative effects in the parents. The ratio $\mathrm{h}^{2} / \mathrm{H}_{2}$ shows the number of groups of genes which control the trait. The proportion of dominance and recessive genes $(\mathrm{KD} / \mathrm{KR})$ in the parents shows that recessive genes are in higher frequency than the dominant genes (Table 4). The operation of recessive genes, presence of overdominance and also the effect of environmental component of variation indicate the complexity of the genetic nature of coconut. Interestingly Liyange and Sakai (1960) found high heritability for number of nuts (48\%) in broad sense as against $9.68 \%$ in the present studies. The present studies used narrow sense heritability using combining ability analysis. Fernando(1996) in the first ever studies on diallel crosses attempted to study the gene action studied mean husked weight and copra weight. We could not find a parallel study in coconut on the gene action for yield of nut. Fernando (1996) also found that non additive genetic component was higher than dominance components. She concluded that neither the presence of heterosis nor inbreeding depression was consistent among the selfed and crossed progenies elucidating that both selfing and crossing could improve the trait depending on the genetic constitution of the individual. 


\section{CONCLUSION}

Combining ability analysis for number of nuts/palm/year using diallel mating design among nine coconut genotypes revealed significant GCA and SCA variance suggesting the preponderance of both additive and non-additive gene action. This shows that breeding strategy involving selection of parents followed by their crossing to impure the nut yield will be highly rewarding. Estimates of GCA and SCA effects showed the parents Laccadive Ordinary and Gangabondam as best general combiners for nuts/palm/year and the cross Laccadive Ordinary x Gangabondam as the best cross combination. The genetic components indicated the presence of over dominance and environmental effects to be more significant.

\section{REFERENCES}

FERNANDO, W.M.U. (1996). Genetic control of husked nut weight in coconut (Cocos nucifera). Cocos 1996, 11:1-6.

GRIFFING, B.(1956). Concept of general and specific combining ability in relation to diallel crossing system. Aust. J.Biol. Sci. 9: 463-493.

HAYMAN, B.I. (1954). The theory and analysis of diallel crosses. Genetics, 39: 789-809.

KHAN, H. HAMEED, BIDDAPPA, C.C. and CECIL, S.R. (1994). Advances in Horticulture Vol.9 Plantation and spice crops Part.I. Eds. K.L. Chadha and P. Rethinam. Malhotra Publishing House, New Delhi, India pp. 375-394.

LIYANAGE, D.V. and K.I. SAKAI (1960). Heritabilities of certain yield characters of the coconut palm. J. Genet. 57: 245-257.

LOUIS HENRY, I. and CHOPRA, V.L. (1991). Exploiting heterosis in coconut palms. In : Coconut breeding and Management edited by E.G. Silas, M. Aravindakshan and A.I. Jose. p. 69-74. 
Table 1: Mean performance of parents and hybrids for number of nuts/palm/year

\begin{tabular}{|c|c|c|c|}
\hline Parent/Hybrid & $\begin{array}{c}\text { No. of nuts/ } \\
\text { palm/year }\end{array}$ & $\begin{array}{l}\text { Parent/ } \\
\text { hybrid }\end{array}$ & $\begin{array}{l}\text { No. of nuts/ } \\
\text { palm/ha/year }\end{array}$ \\
\hline West Coast Tall $\left(\mathrm{P}_{1}\right)$ & 45.4 & $\mathrm{P}_{2} \times \mathrm{P}_{8}$ & 53.6 \\
\hline Laccadive Ordinary $\left(\left(\mathrm{P}_{2}\right)\right.$ & 56.4 & $\mathrm{P}_{2} \times \mathrm{P}_{9}$ & 42.6 \\
\hline $\operatorname{San} \operatorname{Ramon}\left(\mathrm{P}_{3}\right)$ & 14.5 & $\mathrm{P}_{3} \times \mathrm{P}_{4}$ & 20.0 \\
\hline Java $\left(\mathrm{P}_{4}\right)$ & 66.1 & $\mathrm{P}_{3} \times \mathrm{P}_{5}$ & 17.7 \\
\hline Jamaica $\left(\mathrm{P}_{5}\right)$ & 54.3 & $\mathrm{P}_{3} \times \mathrm{P}_{6}$ & 38.7 \\
\hline Fiji $\left(P_{6}\right)$ & 31.9 & $\mathrm{P}_{3} \times \mathrm{P}_{7}$ & 31.5 \\
\hline Gangabondam $\left(\mathrm{P}_{7}\right)$ & 40.4 & $\mathrm{P}_{3} \times \mathrm{P}_{8}$ & 25.5 \\
\hline Straight Settlement Green $\left(\mathrm{P}_{8}\right)$ & 33.2 & $\mathrm{P}_{3} \times \mathrm{P}_{9}$ & 31.7 \\
\hline New Guinea $\left(\mathrm{P}_{9}\right)$ & 49.8 & $\mathrm{P}_{3} \times \mathrm{P}_{5}$ & 33.1 \\
\hline HYBRIDS & & $\mathrm{P}_{4} \times \mathrm{P}_{6}$ & 33.5 \\
\hline $\mathrm{P}_{1} \times \mathrm{P}_{2}$ & 51.6 & $\mathrm{P}_{4} \times \mathrm{P}_{7}$ & 37.5 \\
\hline $\mathrm{P}_{1} \times \mathrm{P}_{3}$ & 43.8 & $\mathrm{P}_{4} \times \mathrm{P}_{8}$ & 39.0 \\
\hline $\mathrm{P}_{1} \times \mathrm{P}_{4}$ & 34.4 & $\mathrm{P}_{4} \times \mathrm{P}_{9}$ & 24.0 \\
\hline $\mathrm{P}_{1} \times \mathrm{P}_{3}$ & 26.8 & $\mathrm{P}_{5} \times \mathrm{P}_{6}$ & 21.0 \\
\hline $\mathrm{P}_{1} \times \mathrm{P}_{6}$ & 40.1 & $\mathrm{P}_{5} \mathrm{xP}_{7}$ & 39.0 \\
\hline $\mathrm{P}_{1} \times \mathrm{P}_{7}$ & 33.7 & $\mathrm{P}_{5} \times \mathrm{P}_{8}$ & 26.5 \\
\hline $\mathrm{P}_{1} \times \mathrm{P}_{8}$ & 43.6 & $\mathrm{P}_{5} \times \mathrm{P}_{9}$ & 38.1 \\
\hline $\mathrm{P}_{1} \times \mathrm{P}_{9}$ & 40.3 & $\mathrm{P}_{6} \times \mathrm{P}_{7}$ & 26.0 \\
\hline $\mathrm{P}_{2} \times \mathrm{P}_{3}$ & 34.4 & $\mathrm{P}_{6} \times \mathrm{P}_{8}$ & 40.5 \\
\hline $\mathrm{P}_{2} \times \mathrm{P}_{4}$ & 42.3 & $\mathrm{P}_{6} \times \mathrm{P}_{9}$ & 52.0 \\
\hline $\mathrm{P}_{2} \times \mathrm{P}_{5}$ & 50.9 & $\mathrm{P}_{7} \times \mathrm{P}_{8}$ & 37.0 \\
\hline $\mathrm{P}_{2} \times \mathrm{P}_{6}$ & 28.7 & $\mathrm{P}_{7} \times \mathrm{P}_{9}$ & 32.0 \\
\hline $\mathrm{P}_{2} \times \mathrm{P}_{7}$ & 102.0 & $\mathrm{P}_{8} \mathrm{x} \mathrm{P}_{9}$ & 29.0 \\
\hline
\end{tabular}


Table 2: Gca (diagonal values) and sca (non-diagonal) effects for number of nuts/palm/year

\begin{tabular}{|c|r|r|r|r|r|r|r|r|r|}
\hline Parents & $\mathrm{P}_{1}$ & $\mathrm{P}_{2}$ & $\mathrm{P}_{3}$ & $\mathrm{P}_{4}$ & $\mathrm{P}_{5}$ & $\mathrm{P}_{6}$ & $\mathrm{P}_{7}$ & $\mathrm{P}_{8}$ & $\mathrm{P}_{9}$ \\
\hline $\mathrm{P}_{1}$ & 9.33 & -5.54 & 53.11 & -9.54 & -46.74 & 11.83 & -40.38 & 19.74 & -4.12 \\
$\mathrm{P}_{2}$ & & 50.82 & -26.26 & -19.16 & 8.06 & -75.38 & 191.75 & 18.17 & -36.07 \\
$\mathrm{P}_{3}$ & & & -38.96 & -18.46 & -35.04 & 54.36 & -1.14 & -4.55 & 9.95 \\
$\mathrm{P}_{4}$ & & & & -14.06 & 1.69 & 8.84 & -0.87 & 23.55 & -45.49 \\
$\mathrm{P}_{5}$ & & & & & -7.02 & -47.70 & -11.16 & -31.86 & 3.56 \\
$\mathrm{P}_{6}$ & & & & & & -12.42 & -48.63 & 29.04 & 66.50 \\
$\mathrm{P}_{7}$ & & & & & & & 14.29 & -10.05 & -42.41 \\
$\mathrm{P}_{8}$ & & & & & & & & -6.13 & -30.53 \\
$\mathrm{P}_{9}$ & & & & & & & & & 4.15 \\
\hline
\end{tabular}

VAR (gi) : 114.5

VAR (sij) : 1185.7

Table 3: Estimates of genetic components of variations

\begin{tabular}{|l|l|}
\hline \multicolumn{1}{|c|}{ Components } & \multicolumn{1}{c|}{ Value } \\
\hline $\mathrm{D}$ & $328.05 \pm 435 / 40$ \\
$\mathrm{H}_{1}$ & $1614.64 \pm 960.00$ \\
$\mathrm{H}_{2}$ & $1452.41 \pm 826.11$ \\
$\mathrm{~h}_{2}$ & $-1390 \pm 553.42$ \\
$\mathrm{~F}$ & $-99.50 \pm 1015.69$ \\
$\mathrm{E}$ & $354.43 \pm 136.69$ \\
\hline
\end{tabular}

Table 4: Proportion of different genetic components of variation

\begin{tabular}{|l|c|}
\hline \multicolumn{1}{|c|}{ Components } & Value \\
\hline$\left(\mathrm{H}_{1} / \mathrm{D}\right)^{1 / 2}$ & 0.22 \\
$\mathrm{H}_{2} / 4 \mathrm{H} 1$ & 0.22 \\
$\mathrm{~h}_{2} / \mathrm{H}_{2}$ & 0.01 \\
$\mathrm{KD} / \mathrm{KR}$ & 0.87 \\
Heritability (n.s.) & 9.48 \\
\hline
\end{tabular}

